Vantage: Journal of Thematic Analysis

ISSN: 2582-7391

A Multidisciplinary Publication of Centre for Research,

Maitreyi College, University of Delhi

April 2020, Volume 1, Issue 1

Original Research Article

\title{
Assessment of Bacteriological and Physico-Chemical Parameters of Drinking Water to Check the Efficacy of Water Purifier Systems
}

\author{
Renu Gupta, Archana Aggarwal*, Annu Kumari, Anamika Sharma, Tanvi Gupta, Diksha \\ Sabharwal, Drushti Sable, Preena and Rishika Maji \\ Department of Zoology, Maitreyi College, Chanakyapuri, New-Delhi-110021 \\ *Correspondence: aaggarwal@ maitreyi.du.ac.in
}

\begin{abstract}
Availability of safe drinking water is a prerequisite for survival and safeguard against various water-borne diseases. The study was carried out with an aim to check the efficacy of water purifier systems by assessing the bacteriological and physico-chemical parameters (temperature, turbidity, pH, TDS, chloride, total hardness, dissolved oxygen, and free $\mathrm{CO}_{2}$ ) in industrial $\mathrm{RO}$ water samples from various outlets at Maitreyi College and household RO and filtered water samples from two residential areas (Satya Niketan and Geeta Colony) located in Delhi, India. The results obtained were compared with the standard values set by the World Health Organisation (WHO) for safe drinking water. Out of total 29 samples analyzed for various physico-chemical parameters, the values of most of the samples were found to be within permissible range. The values of some parameters for drinking water samples collected from filter and RO purifier installed at Geeta colony were above the maximum limit which can pose serious threats to health. The bacteriological examination was assessed by the Most Probable Number (MPN) test and the results of EMB agar plates showed that there is probability of presence of coliform bacteria in 3 samples. The results obtained signify that it is important to check the purity of drinking water at regular intervals irrespective of the fact that it is filtered. Also, it is imperative to ensure regular maintenance of purifier systems installed as they themselves might be the source of impurity.
\end{abstract}

Keywords: Physico-chemical parameters, bacteriological, Most Probable Number (MPN) test, potable water, coliform.

\section{INTRODUCTION}

"Thousands have lived without love, not one without water" (W.H. Auden). The quote signifies the prime importance of access to safe drinking water, a natural asset for the existence of the humanity. Availability of clean drinking water is a fundamental right and thus quality control remains a priority worldwide (Rehmanian et al., 2015). It has been 
reported that the water crisis faced by the world is not due to limitation of resources but a result of mismanagement in policy-making leading to deterioration of environment and health (RIO+25, 2018-2019). In India, 70\% of available drinking water resources have been polluted by direct discharge of industrial, agricultural, and domestic waste without any prior treatment (Kaur \& Kaur, 2015). Consumption of polluted drinking water enhances the susceptibility to various water-borne infections. According to Kumar \& Rao (2012) the occurrence of $80 \%$ of diseases in India is due to consumption of contaminated water. Thus, it is imperative to check the quality of drinking water at regular intervals. An estimated 1.1 billion people in the world do not have access to clean water and annually more than 3.4 million people, consisting mainly of children, die as a result of water related diseases (Mahajan \& Bhardwaj, 2017).

Water purifiers/ filters have been in usage for access to better quality of water since the earliest civilization. Technological advancement and growth in the economy has led to advanced water purifiers which are an essential part of every household. The use of a water purifier/ filter benefits the population in preventing water-borne diseases. Hard water can be converted into soft water using the demineralization property of the modern water purifiers using reverse osmosis (RO) technology. Awareness with respect to the benefits of purified drinking water is still very low in rural India (Kumar \& Rao, 2012). Even the urban population sometimes forgets that water purification systems require regular maintenance and negligence leads to compromise with water quality. Thus, the present study was designed to check the efficacy of water purifiers installed by estimating various parameters for water quality assessment.

\section{METHODOLOGY}

2.1 Sample Sites: Total 29 drinking water samples and one distilled water sample were tested. Water samples were collected from some households at Satya Niketan (Samples 1-9), sources within the Maitreyi college premises (Samples 10-27) and Geeta colony (Samples 2930), Delhi, India. Distilled water i.e. sample 28 was also tested for comparison.

2.2 Sample Collection: The water samples were collected in pre-labeled 1L sterilized polyethylene sampling bottles with no air trapped. Bottles were initially rinsed with the water sample and water was allowed to flow for a few minutes at the source of collection before filling the bottles. Water samples were collected in duplicate from each water source. The 
bottles were brought to the laboratory and all the physico-chemical analyses were done on the same day.

2.3 Physico-chemical Analysis: For the water quality parameters, classical laboratory methods and standard titrimetric procedures (Potentiometirc titration with silver nitrate for Chloride; EDTA titrimetric method for total hardness) were followed (WHO, 1996). All the parameters were tested in triplicates from each sample.

2.4 Biological Analysis: The MPN (Most Probable Number) test is a statistics-based test which estimates the number of fecal coliforms in a water sample based on the degree of lactose fermentation by organisms in the sample (McCardy et al, 1915). It involves multiple tube fermentation tests in which a series of tubes with lactose are inoculated with water samples and the pattern of tubes showing acid and gas is compared to statistical tables which give the probable numbers of coliforms present in water samples (Aneja, 2014).

\section{RESULTS AND DISCUSSION}

\subsection{Physico-chemical Analysis (Table 1; Figures 1\& 2)}

The $\mathbf{p H}$ is considered as a secondary contamination of drinking water. Water with low $\mathrm{pH}$ is acidic, naturally soft and corrosive in nature, while drinking water with $\mathrm{pH}$ above 8.5 indicates the presence of high levels of alkalinity minerals having aesthetic effect (Maskey et al., 2020).According to WHO (2004) guidelines, pH has no direct impact on human health, but is considered as one of the most important operational water quality parameters. The $\mathrm{pH}$ of tested samples ranged from 5.83 to 7.5. Most of the samples from Satya Niketan and Maitreyi College had values lower than the range as per WHO standards.

Temperature is important for physical, chemical and biological properties of water. The water samples analysed had temperatures that ranged from $14.00{ }^{\circ} \mathrm{C}$ to $38.50{ }^{\circ} \mathrm{C}$ depending upon direct/ cooler/ dispenser outlet and also the environmental temperature.

Total dissolved solids (TDS) levels may produce aesthetically displeasing colour, taste and odour. Water with higher solid content often has a laxative and sometimes the reverse effect upon people whose bodies are not adjusted to them. In the samples analysed, the values of TDS were in the range 11.67-1553.33. Sample 29 had very high TDS, three times more than the maximum permissible value provided by WHO, i.e. $500 \mathrm{mg} / \mathrm{L}$. Although TDS of almost all the samples (except one sample) were found to be within the range of standard value, most of the samples had very low TDS value indicating probability of loss of minerals. 
Turbidity in water increases temperature of water as the suspended particles absorb more heat. Clear water is generally associated with low temperature. The water samples were clear and showed no signs of turbidity.

Dissolved oxygen (DO) refers to the volume of oxygen that is contained in water. A high DO level in a community water supply is good because it makes drinking water taste better. DO of analyzed samples ranged from 3.33 to $8.87 \mathrm{mg} / \mathrm{L}$. DO levels increase because air is trapped under rapidly moving water (running tap water) and the oxygen from the air dissolves in the water. Water temperature also affects DO levels. Cold water can hold more oxygen in it than warmer water. Desirable value of DO in drinking water is $6 \mathrm{mg} / \mathrm{L}$ as per WHO guidelines (2011). Most of the samples had dissolved oxygen value more than the WHO standard value.

Carbon dioxide is present in free state or in the form of $\mathrm{CO}_{2}$ or in dissolved state in the form of carbonate ions and bicarbonate ions. At $\mathrm{pH}$ lower than 4.3 almost all the bicarbonate is converted to carbonic acid which can be toxic even at $\mathrm{pH}$ values that are not in themselves harmful. High concentrations of dissolved carbon dioxide are corrosive. Free carbon dioxide in domestic water is of no significance because it appears to have no direct physiological effect. Free carbon dioxide in the water samples was found to be in the range 2.20-17.60 $\mathrm{mg} / \mathrm{L} .10$ out of 30 samples have free $\mathrm{CO}_{2}$ greater than $6 \mathrm{mg} / \mathrm{L}$ which is the standard free $\mathrm{CO}_{2}$ value in drinkable water as prescribed by WHO.

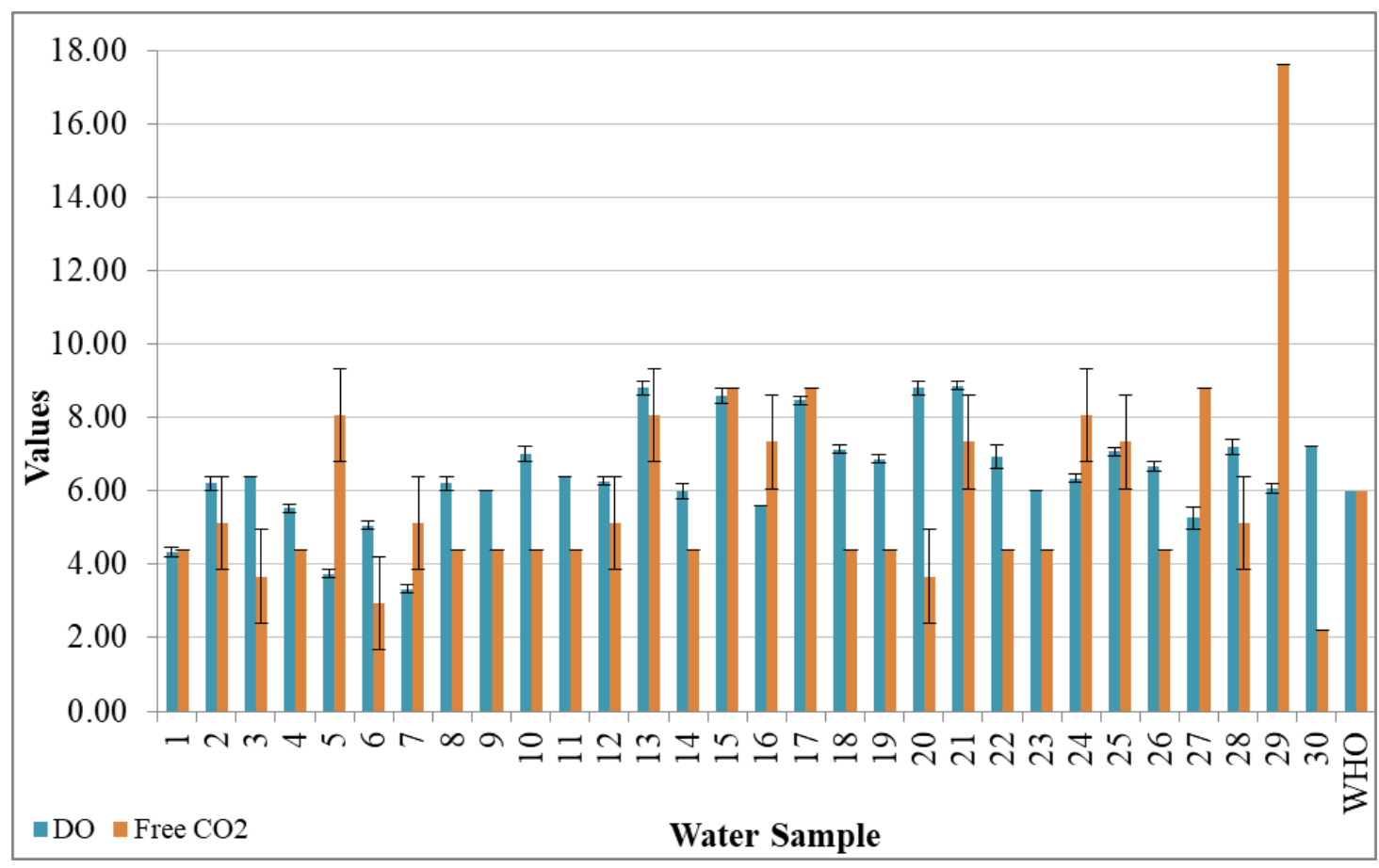

Figure 1: Comparative analysis of Dissolved Oxygen (DO) and free $\mathrm{CO}_{2}$ values 
Hardness is the property of water that prevents lathering of soap. Calcium and magnesium polyvalent cations cause hardness in water and their concentration can determine the degree of hardness. Water with hardness greater than $200 \mathrm{mg} / \mathrm{L}$ is considered poor and water with hardness greater than $500 \mathrm{mg} / \mathrm{L}$ is normally considered unacceptable for domestic purposes. Total hardness of collected samples varied from 6.0 to $266.67 \mathrm{mg} / \mathrm{L}$. Total hardness of most of the samples were found to be within the standard value given by WHO (2011), except for the samples 5 (Satya Niketan) and 29 (Geeta Colony).

Chloride is one of the major inorganic anions in water leading to salty taste. Its concentration in water samples was found to be in the range 15.4-460.85 mg/L. Chloride concentration of almost all the samples was found to be lower than the standard values $(200 \mathrm{mg} / \mathrm{L})$ given by WHO (Edition, 2011) except for samples from Geeta colony (29 and 30). Higher than normal chloride concentration is detrimental to water quality and is corrosive in nature.

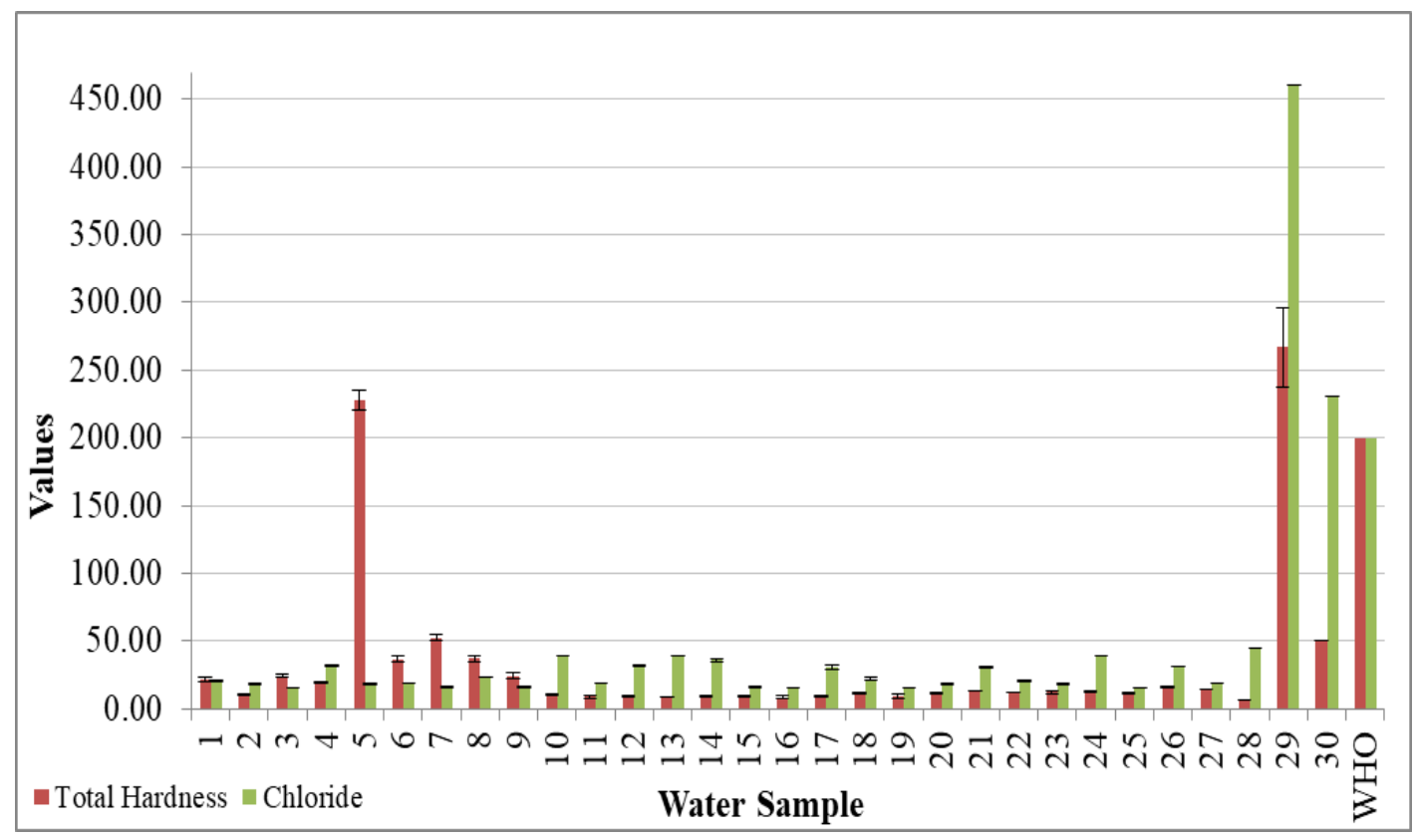

Figure 2: Comparative analysis of Total Hardness and Chloride values

Table 1: Comparative analysis of physico-chemical parameters of the water samples analyzed (Value \pm SD)

\begin{tabular}{|c|c|c|c|c|c|c|c|}
\hline $\begin{array}{l}\text { Sample } \\
\text { Code }\end{array}$ & $\mathbf{p H}$ & $\begin{array}{l}\text { Temperature } \\
\left({ }^{\circ} \mathbf{C}\right)\end{array}$ & $\begin{array}{l}\text { Total } \\
\text { Dissolved } \\
\text { Solids (TDS) } \\
(\mathrm{mg} / \mathrm{L})\end{array}$ & $\begin{array}{l}\text { Total } \\
\text { Hardness } \\
(\mathrm{mg} / \mathrm{L})\end{array}$ & $\begin{array}{l}\text { Dissolved } \\
\text { Oxygen } \\
(\mathrm{DO}) \\
(\mathrm{mg} / \mathrm{L})\end{array}$ & $\begin{array}{l}\text { Free } \\
\text { Carbon } \\
\text { Dioxide } \\
\left(\mathrm{CO}_{2}\right) \\
(\mathrm{mg} / \mathrm{L})\end{array}$ & $\begin{array}{l}\text { Chloride } \\
\text { Ions } \\
(\mathrm{mg} / \mathrm{L})\end{array}$ \\
\hline
\end{tabular}




\begin{tabular}{|c|c|c|c|c|c|c|c|}
\hline 1 & $6.5 \pm 0.5$ & $33.67 \pm 0.58$ & $44.33 \pm 2.08$ & $21.67 \pm 1.53$ & $4.33 \pm 0.12$ & $4.4 \pm 0$ & $20.67 \pm 0.58$ \\
\hline 2 & $6 \pm 0$ & $30.5 \pm 0.5$ & $20.33 \pm 1.53$ & $10.17 \pm 0.76$ & $6.2 \pm 0.2$ & $5.13 \pm 1.27$ & $18.24 \pm 0.21$ \\
\hline 3 & $6.67 \pm 0.29$ & $28.17 \pm 0.76$ & $47.33 \pm 2.52$ & $24 \pm 1$ & $6.4 \pm 0$ & $3.67 \pm 1.27$ & $15.4 \pm 0.36$ \\
\hline 4 & $5.83 \pm 0.29$ & $36 \pm 1$ & $37.33 \pm 2.52$ & $19.17 \pm 0.76$ & $5.53 \pm 0.12$ & $4.4 \pm 0$ & $31.5 \pm 0.5$ \\
\hline 5 & $7.5 \pm 0$ & $37.83 \pm 0.29$ & $449.33 \pm 9.02$ & $228 \pm 7.55$ & $3.73 \pm 0.12$ & $8.07 \pm 1.27$ & $18.5 \pm 0.38$ \\
\hline 6 & $6 \pm 0$ & $38.5 \pm 0.5$ & $73.67 \pm 5.13$ & $36.67 \pm 2.08$ & $5.07 \pm 0.12$ & $2.93 \pm 1.27$ & $18.37 \pm 0$ \\
\hline 7 & $6 \pm 0$ & $30.5 \pm 0.5$ & $105.67 \pm 5.51$ & $52.33 \pm 2.08$ & $3.33 \pm 0.12$ & $5.13 \pm 1.27$ & $15.7 \pm 0.3$ \\
\hline 8 & $6 \pm 0$ & $33.83 \pm 0.76$ & $68.67 \pm 4.04$ & $36.83 \pm 2.02$ & $6.2 \pm 0.2$ & $4.4 \pm 0$ & $23.63 \pm 0.06$ \\
\hline 9 & $6.17 \pm 0.29$ & $29.5 \pm 0.5$ & $48 \pm 2.65$ & $24.17 \pm 2.02$ & $6 \pm 0$ & $4.4 \pm 0$ & $15.63 \pm 0.6$ \\
\hline 10 & $6.33 \pm 0.29$ & $30.17 \pm 0.76$ & $20.33 \pm 1.53$ & $10.17 \pm 0.76$ & $7 \pm 0.2$ & $4.4 \pm 0$ & $39.12 \pm 0.21$ \\
\hline 11 & $6 \pm 0$ & $14.83 \pm 0.76$ & $20.33 \pm 2.52$ & $9 \pm 1$ & $6.4 \pm 0$ & $4.4 \pm 0$ & $18.41 \pm 0.08$ \\
\hline 12 & $6 \pm 0$ & $14 \pm 0.5$ & $19.33 \pm 2.52$ & $9.17 \pm 0.29$ & $6.27 \pm 0.12$ & $5.13 \pm 1.27$ & $31.67 \pm 0.76$ \\
\hline 13 & $6 \pm 0$ & $15 \pm 0$ & $19 \pm 1$ & $9 \pm 0$ & $8.8 \pm 0.2$ & $8.07 \pm 1.27$ & $39.25 \pm 0.21$ \\
\hline 14 & $6 \pm 0$ & $14.17 \pm 0.29$ & $19.67 \pm 2.08$ & $9.5 \pm 0.5$ & $6 \pm 0.2$ & $4.4 \pm 0$ & $35.75 \pm 0.66$ \\
\hline 15 & $6 \pm 0$ & $29 \pm 1$ & $20.33 \pm 1.53$ & $9.33 \pm 0.29$ & $8.6 \pm 0.2$ & $8.8 \pm 0$ & $15.8 \pm 0.36$ \\
\hline 16 & $6 \pm 0$ & $19.17 \pm 1.04$ & $19.33 \pm 0.58$ & $8.5 \pm 0.87$ & $5.6 \pm 0$ & $7.33 \pm 1.27$ & $15.7 \pm 0$ \\
\hline 17 & $6 \pm 0$ & $15.5 \pm 0.5$ & $19.33 \pm 1.15$ & $9.67 \pm 0.58$ & $8.47 \pm 0.12$ & $8.8 \pm 0$ & $30.67 \pm 1.44$ \\
\hline 18 & $6 \pm 0$ & $15.83 \pm 0.76$ & $23.67 \pm 1.53$ & $11.17 \pm 0.76$ & $7.13 \pm 0.12$ & $4.4 \pm 0$ & $21.73 \pm 1.1$ \\
\hline 19 & $6 \pm 0$ & $15.17 \pm 0.76$ & $18.33 \pm 0.58$ & $9.33 \pm 1.26$ & $6.87 \pm 0.12$ & $4.4 \pm 0$ & $15.7 \pm 0.2$ \\
\hline 20 & $6 \pm 0$ & $17 \pm 1$ & $25.33 \pm 2.31$ & $11.67 \pm 0.58$ & $8.8 \pm 0.2$ & $3.67 \pm 1.27$ & $18.46 \pm 0.51$ \\
\hline 21 & $6 \pm 0$ & $20.5 \pm 0.5$ & $25 \pm 1$ & $13 \pm 0$ & $8.87 \pm 0.12$ & $7.33 \pm 1.27$ & $30.83 \pm 0.76$ \\
\hline 22 & $6 \pm 0$ & $29.5 \pm 0.5$ & $24 \pm 1$ & $12.17 \pm 0.29$ & $6.93 \pm 0.31$ & $4.4 \pm 0$ & $20.5 \pm 0.5$ \\
\hline 23 & $6 \pm 0$ & $17 \pm 1$ & $24.33 \pm 0.58$ & $12.17 \pm 1.04$ & $6 \pm 0$ & $4.4 \pm 0$ & $18.56 \pm 0.39$ \\
\hline 24 & $6 \pm 0$ & $23.67 \pm 0.58$ & $25 \pm 1$ & $12.33 \pm 0.58$ & $6.33 \pm 0.12$ & $8.07 \pm 1.27$ & $39.29 \pm 0.26$ \\
\hline 25 & $6 \pm 0$ & $20.33 \pm 0.58$ & $23.67 \pm 1.53$ & $11.67 \pm 0.58$ & $7.07 \pm 0.12$ & $7.33 \pm 1.27$ & $15.47 \pm 0.4$ \\
\hline
\end{tabular}




\begin{tabular}{|l|l|l|l|l|l|l|l|}
26 & $6.17 \pm 0.29$ & $20 \pm 0$ & $29.67 \pm 1.53$ & $15.67 \pm 0.76$ & $6.67 \pm 0.12$ & $4.4 \pm 0$ & $31.17 \pm 0.29$ \\
\hline 27 & $6.33 \pm 0.29$ & $23.67 \pm 0.58$ & $28.67 \pm 3.51$ & $14.17 \pm 0.29$ & $5.27 \pm 0.31$ & $8.8 \pm 0$ & $18.37 \pm 0$ \\
\hline 28 & $6.17 \pm 0.29$ & $30.33 \pm 0.58$ & $11.67 \pm 0.58$ & $6 \pm 0$ & $7.2 \pm 0.2$ & $5.13 \pm 1.27$ & $44.62 \pm 0$ \\
\hline 29 & $7.5 \pm 0$ & $35 \pm 0$ & $1553.33 \pm 11.55$ & $266.67 \pm 28.87$ & $6.07 \pm 0.12$ & $17.6 \pm 0$ & $460.85 \pm 0$ \\
\hline 30 & $7 \pm 0$ & $27 \pm 0$ & $120 \pm 0$ & $50 \pm 0$ & $7.2 \pm 0$ & $2.2 \pm 0$ & $230.42 \pm 0$ \\
\hline WHO & $6.5-8.5$ & & 500 & 200 & 4 to 6 & 6 & 200 \\
\hline
\end{tabular}

\subsection{Bacteriological analysis for Coliform test or Most Probable Number test (Table 2;}

\section{Figures 3 \& 4)}

Microbial drinking water quality testing plays an essential role in measures to protect public health. Bacterial count in water is a key factor in assessing the quality of drinking water (Nkere, 2011).It can be done using many methods, one of them being the MPN method. MPN tests rely on sample division or dilution and statistical methods to estimate the level of contamination (Bain et al., 2012).MPN tests were performed for all the water samples for presence of bacteria and some of the samples tested positive. Presence of bacterial colonies on EMB agar plates showed the probability of presence of coliform bacteria in 3 samples. Further confirmatory tests are required to identify the nature of these colonies.

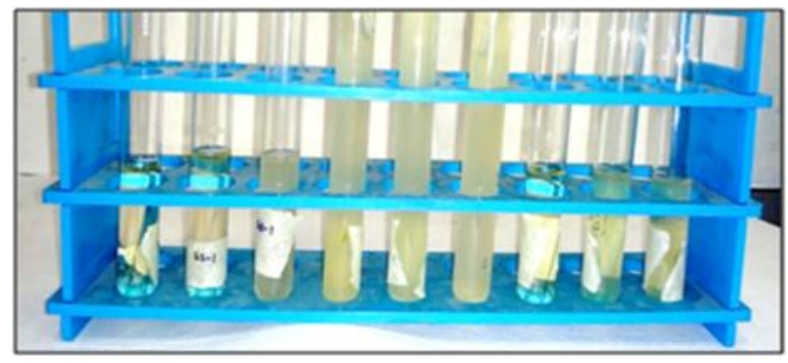

Figure 3:Test tubes showing positive results for MPN test

Table 2: Water samples showing positive results for MPN test

\begin{tabular}{|l|l|l|l|c|}
\hline $\begin{array}{l}\text { Sample } \\
\text { Code }\end{array}$ & $\begin{array}{l}\text { Three of } \\
10 \mathrm{ml} \text { each }\end{array}$ & $\begin{array}{l}\text { Three of } \\
1 \mathrm{ml} \text { each }\end{array}$ & $\begin{array}{l}\text { Three of } \\
\text { 0.1ml each }\end{array}$ & $\begin{array}{l}\text { MPN index } \\
\text { per 100ml }\end{array}$ \\
\hline 1 & 2 & 1 & 1 & 9 \\
\hline 2 & 2 & 1 & 1 & 9 \\
\hline 27 & 2 & 1 & 0 & 7 \\
\hline
\end{tabular}




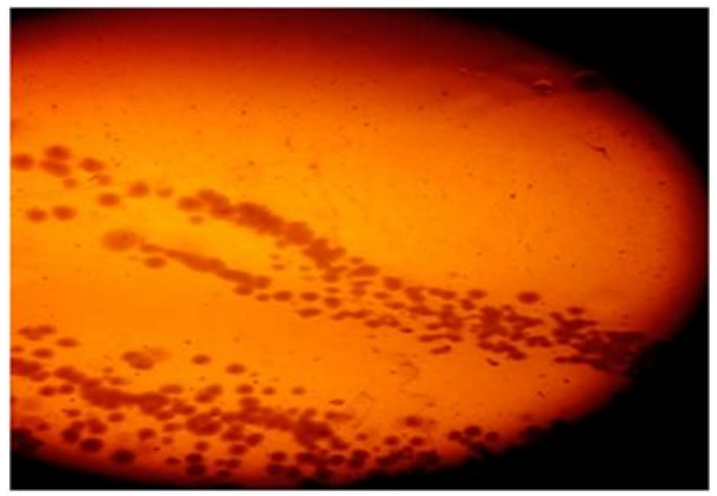

Figure 4: Bacterial colonies in Eosine Methylene Blue agar plate from water sample number 1

\section{CONCLUSION}

The quality of filtered drinking water (either through RO or through a candle filter) samples from Maitreyi College, Satya Niketan and Geeta colony is appreciable but certain parameters need attention. The recently installed industrial RO at Maitreyi has multiple outlets for the supply of potable water. The entire network of RO water using a food grade water supply system for all outlets is functioning efficiently ensuring supply of good quality water but the TDS value was low and the problem was rectified by the authorities after the results were conveyed. One of the samples collected using an external extra pipe showed presence of bacteria indicating that the food grade material is important for any potable water supply and such attachments are not advisable. The quality analysis of samples from Satya Niketan and Geeta Colony emphasise the need for proper maintenance of filters and RO water purifier systems. It is the responsibility of the user to take ample steps for supply of safe drinking water to reduce the risk of water-borne diseases. The individual households were informed about the quality of water and awareness was generated for enforcement of continuous monitoring of water quality and maintenance of the water purifier systems as prime priority. Further work is being planned to identify and analyze the type of microbial contamination in the analyzed samples.

\section{CONFLICT OF INTEREST STATEMENT}

The authors declare that there is no conflict of interest.

\section{SOURCE OF FUNDING}

We would like to thank Maitreyi College, University of Delhi for funding the expenses of this research project. 


\section{ACKNOWLEDGEMENTS}

We are highly thankful to the Principal, Maitreyi College, University of Delhi for her constant support and encouragement. Authors acknowledge the help and support extended by the laboratory staff, Zoology Department, Maitreyi College.

\section{REFERENCES}

Aneja, K.R. (2014). Laboratory Manual of Microbiology and Biotechnology. New Delhi: Scientific International Pvt.limited.

Bain, R., Bartram, J., Elliott, M., Matthews, R., McMahan, L., Tung, R., Chuang, P. \& Gundry, S. (2012). A summary catalogue of microbial drinking water tests for low and medium resource settings. International journal of environmental research and public health, 9(5), 1609-1625. https://doi.org/10.3390/ijerph9051609.

Edition, F. (2011). Guidelines for drinking-water quality. WHO chronicle, 38(4), 104-8.

Kaur, J. \& Kaur, H. (2015). Water Potability of Drinking Water collected from sub Regions of district Jalandhar, Punjab, India: A Review. International Research Journal of Biological Sciences, 49(10), 62-65.

Kumar, N. S. \& Rao, D. V. (2012). Competitor analysis of water purifiers an emperical study with reference to pure-it (Hindustan Unilever Ltd) at Warangal-Andhrapradesh. International Journal of Marketing, Financial Services \& Management Research. $1(8), 187-195$.

Mahajan, M. \& Bhardwaj, K. (2017). Potability analysis of drinking water in various regions of Ludhiana district, Punjab, India. International research journal of pharmacy, 8, 87-90. https://doi.org/10.7897/2230-8407.086102.

Maskey, M., Annavarapu, L. S., Prasai, T. \& Bhatta, D. R. (2020). Physical, chemical and microbiological analysis of bottled water in Pokhara, Nepal. Journal of Chitwan Medical College, 10(2), 25-28.

McCrady, M. H. (1915). The numerical interpretation of fermentation-tube results. The Journal of Infectious Diseases, 183-212.

Nkere, C. K., Ibe, N. I. \& Iroegbu, C. U. (2011). Bacteriological quality of foods and water sold by vendors and in restaurants in Nsukka, Enugu State, Nigeria: a comparative study of three microbiological methods. Journal of health, population, and nutrition, 29(6), 560-566. https://doi.org/10.3329/jhpn.v29i6.9892. 
Rahmanian, N., Ali, S. H. B., Homayoonfard, M., Ali, N. J., Reham, M., Sadef, Y. \& Nizami, A. S. (2015). Analysis of Physiochemical Parameters to Evaluate the Drinking Water Quality in the State of Perak, Malaysia. Journal of Chemistry. 2015. Article ID 716125. 10 pages. http://dx.doi.org/10.1155/2015/716125

RIO+25 India Program 2018-2028. Water Action Decade.

World Health Organization \& International Programme on Chemical Safety (1996). Guidelines for drinking-water quality. Vol. 2, Health criteria and other supporting information, 2nd ed. World Health Organization. https://apps.who.int/iris/handle/10665/38551

World Health Organization. Water, Sanitation and Health Team (2004). Guidelines for drinking-water quality. Vol. 1, Recommendations, 3rd ed. World Health Organization. https://apps.who.int/iris/handle/10665/42852

How to cite this article: Gupta, R., Aggarwal, A., Kumari, A., Sharma, A., Gupta, T., Sabharwal, D., Sable, D., Preena \& Maji, R. (2020). Assessment of Bacteriological and Physico-Chemical Parameters of Drinking Water to Check the Efficacy of Water Purifier Systems. Vantage: Journal of Thematic Analysis, 1(1): 7-16.

DOI: https://doi.org/10.52253/vjta.2020.v01i01.02

(C) The Author(s) 2020.

This work is licensed under a Creative Commons Attribution 4.0 International License which permits its use, distribution and reproduction in any medium, provided the original work is cited. 